\title{
Penerapan Model Pembelajaran Kooperatif Tipe Make A Match Pada Mata Pelajaran IPS Pokok Bahasan Perjuangan Dalam Mempersiapkan Kemerdekaan Indonesia Untuk Meningkatkan Hasil Belajar Siswa Kelas VA SDN Klatakan 01 Jember
}

\author{
Yulia Ismawati, Muhtadi Irvan, Chumi Zahroul Fitriyah \\ Jurusan Ilmu Pendidikan, Fakultas Keguruan dan Ilmu Pendidikan, Universitas Jember (UNEJ) \\ Jalan Kalimantan Nomor 37, Jember 68121 \\ E-mail:muhtadiirvan@gmail.com
}

\begin{abstract}
Abstrak
Tujuan umum dalam penelitian ini adalah untuk meningkatkan hasil belajar siswa kelas VA SDN Klatakan 01 Jember melalui penerapan model pembelajaran kooperatif tipe Make A Match pada mata pelajaran IPS pokok bahasan perjuangan dalam mempersiapkan kemerdekaan Indonesia. Berdasarkan tujuan tersebut, latar belakang penelitian ini adalah rendahnya hasil belajar siswa kelas VA SDN Klatakan 01 Jember dalam pembelajaran IPS yang disebabkan pelaksanaan pembelajaran masih belum menerapkan model pembelajaran yang bervariatif sehingga siswa cenderung bosan. Salah satu upaya untuk meningkatkan hasil belajar siswa kelas VA SDN Klatakan 01 Jember dalam pembelajaran IPS adalah dengan menerapkan model pembelajaran kooperatif tipe Make A Match. Jenis penelitian ini adalah Penelitian Tindakan Kelas (PTK) yang terdiri dari 2 siklus dengan 4 tahapan yaitu perencanaan, pelaksanaan, pengamatan, dan refleksi. Subjek penelitian adalah siswa kelas VA SDN Klatakan 01 Jember yang berjumlah 22 siswa, yang terdiri atas 12 siswa laki-laki dan 10 siswa perempuan. Metode pengumpulan data dilakukan dengan wawancara, observasi, dokumentasi, dan tes. Hasil penelitian menunjukkan bahwa penerapan model pembelajaran kooperatif tipe Make A Match pada mata pelajaran IPS pokok bahasan perjuangan dalam mempersiapkan kemerdekaan Indonesia dapat meningkatkan hasil belajar siswa kelas VA SDN Klatakan 01 Jember. Skor rata-rata hasil belajar siswa pada prasiklus sebesar 64,81 meningkat menjadi 71,32 pada siklus I dan meningkat lagi menjadi 76,21 pada siklus II.
\end{abstract}

Kata Kunci: hasil belajar siswa, model pembelajaran kooperatif tipe make a match, penelitian tindakan kelas.

\section{Abstract}

The public purpose of this research is to improve learning outcomes of students VA grades SDN Klatakan 01 Jember by application of cooperative learning model type Make a Match in the social science on subject struggle in preparing for Indonesian independence. Based on these objectives, the background of this research is that low learning outcomes of VA class students at SDN Klatakan 01 Jember in social studies learning due to the implementation of learning not usually applied a varied learning model, so students tend to be bored. One effort to improve that learning outcomes of VA class students at SDN Klatakan 01 Jember in social studies learning is to apply the Make A Match type Cooperative Learning Model. This type of research is Classroom Action Research (CAR) which consists of 2 cycles with 4 stages, namely planning, implementation, observation, and reflection. The research subjects were 22 students of VA class SDN Klatakan 01 Jember, consisting of 12 male students and 10 female students. The method of data collection is done by interviews, observation, documentation, and tests. The results showed that the application of the Make A Match type of Cooperative Learning Model on social studies subjects the subject of the struggle in preparing for Indonesian independence could improve the learning outcomes of VA class students at SDN Klatakan 01 Jember. The average score of student learning outcomes on the cycle of 64.81 increased to 71.32 in the first cycle and increased again to 76.21 in the second cycle.

Keywords : learning outcomes of students, cooperative learning model type make a match, classroom action research.

\section{Pendahuluan}

Persaingan global serta perkembangan zaman yang begitu pesat menuntut adanya peningkatan mutu pendidikan di Indonesia agar dapat menciptakan sumber daya manusia yang berkualitas. Pendidikan yang dapat dikatakan bermutu adalah pendidikan yang berhasil membentuk generasi muda yang cerdas, berkarakter, bermoral, dan berkepribadian.

Terkait dengan mutu pendidikan khususnya pada jenjang Sekolah Dasar sampai saat ini masih jauh dari apa yang diharapkan. Kegiatan pembelajaran di Sekolah Dasar pada umumnya masih cenderung monoton serta kurang menarik minat siswa untuk belajar. Hal ini disebabkan karena guru lebih sering menggunakan metode ceramah dan kurang menerapkan model pembelajaran yang bervariasi sehingga siswa juga cenderung kurang termotivasi untuk belajar. Berdasarkan hal tersebut maka mata pelajaran yang diajarkan guru akan dianggap sulit oleh siswa terutama mata pelajaran Ilmu Pengetahuan Sosial (IPS) yang kebanyakan diajarkan guru dengan metode ceramah. 
Berdasarkan hasil observasi dan wawancara yang telah dilakukan dengan guru kelas VA di SDN Klatakan 01 Jember pada 25 Juli 2018, ditemukan penguasaan kompetensi pengetahuan IPS terutama hasil belajar siswa di kelas VA masih kurang optimal. Penguasaan kompetensi pengetahuan siswa dikatakan tuntas bila memenuhi Kriteria Ketuntasan Minimal (KKM) yaitu 70. Dari seluruh siswa yang berjumlah 22 orang, siswa yang tergolong tuntas 9 orang siswa $(40,91 \%)$ dan yang tidak tuntas berjumlah 13 orang siswa $(59,09 \%)$. Data penguasaan kompetensi pengetahuan IPS tersebut diperoleh menggunakan data nilai tes ulangan siswa pada mata pelajaran IPS.

Setelah dikaji, teridentifikasi beberapa faktor yang menyebabkan rendahnya penguasaan kompetensi IPS siswa yakni pemilihan model pembelajaran yang kurang tepat membuat proses pembelajaran menjadi kurang menarik, siswa merasa bosan, kurang komunikatif, aktif dan partisipasi yang rendah dalam kegiatan pembelajaran. Siswa sulit diajak untuk aktif mengungkapkan pendapat yang bertujuan untuk mengembangkan kemampuan siswa dalam berpikir kritis. Hal ini dikarenakan pemahaman dalam konsep belajar pemecahan masalah yang belum dikuasai oleh beberapa siswa yang menyebabkan hasil belajar siswa cenderung kurang maksimal. Perlu tindakan yang tepat agar siswa dapat mencapai KKM yang telah ditetapkan sehingga tujuan pembelajaran dapat tercapai.

Tindakan yang dilakukan dalam penelitian ini yaitu dengan menerapkan alternatif pembelajaran yaitu model pembelajaran kooperatif tipe Make A Match. Model pembelajaran kooperatif tipe Make $A$ Match merupakan model pembelajaran yang di dalamnya terdapat kegiatan melakukan permainan kartu pasangan. Model pembelajaran kooperatif tipe Make A Match mengutamakan penanaman kemampuan sosial terutama kemampuan bekerja sama, kemampuan berinteraksi di samping kemampuan berpikir cepat melalui permainan mencari pasangan menggunakan kartu.

Menurut Rusman (2011:223), langkah-langkah model pembelajaraan kooperatif tipe Make A Match adalah (1) guru menyiapkan topik dalam pembelajaran, (2) tiap siswa mendapat satu buah kartu, (3) siswa memikirkan jawaban/soal dari kartu yang didapat, (4) setiap siswa mencari pasangan dari kartu yang didapatnya, (5) Siswa yang mendapatkan kartu pasangannya diberi poin, (6) setelah satu babak, kartu dikocok lagi, dan (7) kesimpulan [1]. Menurut Huda (2013:253), model pembelajaran kooperatif tipe Make A Match dapat diterapkan pada proses pembelajaran IPS karena selain mengajak siswa untuk dapat berpikir cepat, tipe pembelajaran ini juga mengajak siswa untuk melakukan aktivitas fisik ketika mencari pasangan, sehingga siswa merasa senang dengan permainan yang dilakukan [2]. Model pembelajaran yang sesuai karakteristik siswa tentu akan menambah motivasi siswa untuk belajar sehingga pemahaman serta hasil belajar siswa dapat meningkat. Hal ini menjadi salah satu alasan model pembelajaran kooperatif tipe Make A Match sangat cocok diterapkan dalam pembelajaran di Sekolah Dasar khususnya pada mata pelajaran IPS.

Berdasarkan uraian di atas, maka dilaksanakan penelitian dengan judul "Penerapan Model Pembelajaran Kooperatif
Tipe Make A Match pada Mata Pelajaran IPS Pokok Bahasan Perjuangan dalam Mempersiapkan Kemerdekaan Indonesia untuk Meningkatkan Hasil Belajar Siswa Kelas VA SDN Klatakan 01 Jember".

\section{Metode Penelitian}

Jenis penelitian yang digunakan adalah penelitian tindakan kelas (PTK) dengan model penelitian secara garis besar mencakup empat tahapan yaitu perencanaan, pelaksanaan, pengamatan dan dan refleksi [3]. Penelitian ini dilaksanakan sebanyak dua siklus. Subjek dalam penelitian ini adalah siswa kelas VA SDN Klatakan 01 Jember tahun pelajaran 2018/2019 dengan jumlah 22 siswa, yang terdiri atas 12 siswa laki-laki dan 10 siswa perempuan.

Pada penelitian tindakan kelas ini digunakan 4 metode pengumpulan data yaitu wawancara, observasi, dokumentasi, dan tes. Wawancara dalam penelitian ini bertujuan untuk mengetahui metode pembelajaran yang sering guru terapkan di kelas, hasil belajar siswa dalam pembelajaran IPS, serta kesulitan siswa dalam pembelajaran. Observasi digunakan untuk mengetahui gaya mengajar guru selama proses pembelajaran. Dokumentasi dilakukan untuk mendapatkan daftar nama siswa dan daftar nilai siswa kelas VA SDN Klatakan 01 Jember Tahun Pelajaran 2018/2019 dalam pembelajaran IPS. Tes tulis dilakukan pada setiap akhir siklus yang menggunakan tes tulis bentuk objektif untuk mengukur kemampuan kognitif siswa.

Analisis data dalam penelitian ini diperoleh dari hasil belajar siswa. Menurut Masyhud [4], kriteria hasil belajar siswa dapat dilihat pada tabel 1 .

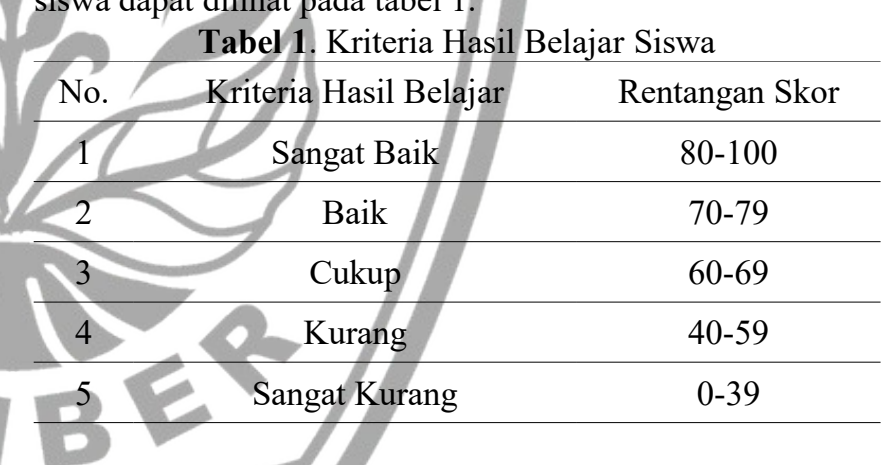

Dalam menentukan pencapaian hasil belajar siswa pada mata pelajaran IPS pokok bahasan perjuangan dalam mempersiapkan kemerdekaan Indonesia setelah proses pembelajaran dengan menerapkan model Make A Match digunakan rumus sebagai berikut.

$$
P=\frac{n}{N} x 100 \%
$$

Keterangan:

$\mathrm{P}=$ Persentase hasil belajar siswa

$\mathrm{n}=$ jumlah siswa yang tuntas

$\mathrm{N}=$ Jumlah seluruh siswa

\section{Hasil dan Pembahasan}

Hasil dari tindakan pendahuluan digunakan sebagai acuan untuk merancang rencana pembelajaran yang digunakan pada siklus I. Hasil refleksi dari pelaksanaan siklus I digunakan untuk melaksanakan tindakan perbaikan yang diaplikasikan pada siklus II. 
Analisis Hasil Belajar Prasiklus

Analisis hasil belajar prasiklus dapat dilihat pada tabel 2 berikut.

Tabel. 2 Analisis Hasil Belajar Prasiklus

\begin{tabular}{|c|c|c|c|c|}
\hline No. & $\begin{array}{c}\text { Rentangan } \\
\text { Skor }\end{array}$ & $\begin{array}{c}\text { Kriteria Hasil } \\
\text { Belajar }\end{array}$ & $\begin{array}{l}\text { Jumlah } \\
\text { Siswa }\end{array}$ & Persentase \\
\hline 1 & $80-100$ & Sangat Baik & 0 & $0.00 \%$ \\
\hline 2 & $70-79$ & Baik & 9 & $40,91 \%$ \\
\hline 3 & $60-69$ & Cukup & 8 & $36,36 \%$ \\
\hline 4 & $40-59$ & Kurang & 5 & $22,73 \%$ \\
\hline 5 & $0-39$ & Sangat Kurang & 0 & $0.00 \%$ \\
\hline & \multicolumn{2}{|c|}{ Jumlah } & 22 & $100.00 \%$ \\
\hline
\end{tabular}

Berdasarkan tabel 2, hasil belajar siswa sebelum penerapan model pembelajaran kooperatif tipe Make A Match pada pembelajaran IPS yaitu terdapat 9 siswa dengan kategori baik (40,91\%), 8 siswa $(36,36 \%)$ termasuk kategori cukup, 5 siswa $(22,73 \%)$ untuk kategori kurang, dan tidak terdapat siswa dengan kategori sangat baik dan sangat kurang. Skor rata-rata hasil belajar siswa secara klasikal sebesar 64,81 termasuk dalam kategori cukup.

\section{Analisis Hasil Belajar Siklus I}

Analisis hasil belajar siklus I dapat dilihat pada tabel 3 berikut.

Tabel 3. Analisis Hasil Belajar Siklus I

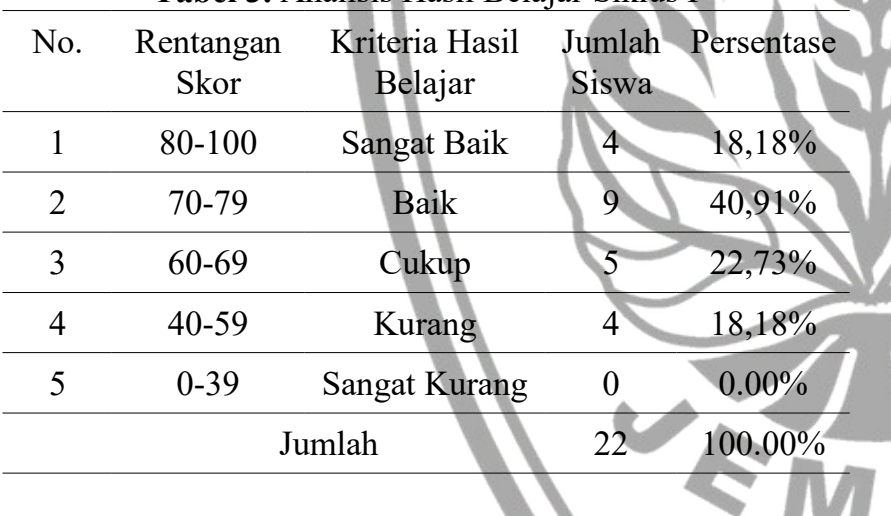

Berdasarkan Tabel 3, hasil belajar siswa pada siklus I mengalami peningkatan. Hasil belajar siswa pada siklus I dengan kriteria sangat baik sebesar $18,18 \%$ (4 siswa), kategori baik sebesar 40,91\% (9 siswa), kategori cukup sebesar 22,73\% (5 siswa), kategori kurang sebesar 18,18\% (4 siswa), dan kategori sangat kurang sebesar $0 \%$.

\section{Analisis Hasil Belajar Siklus II}

Analisis hasil belajar siklus II dapat dilihat pada tabel 4 berikut.

Tabel 4. Analisis Hasil Belajar Siklus II

\begin{tabular}{ccccc}
\hline No. & $\begin{array}{c}\text { Rentangan } \\
\text { Skor }\end{array}$ & $\begin{array}{c}\text { Kriteria Hasil } \\
\text { Belajar }\end{array}$ & $\begin{array}{c}\text { Jumlah } \\
\text { Siswa }\end{array}$ & Persentase \\
\hline 1 & $80-100$ & Sangat Baik & 8 & $36,36 \%$ \\
\hline 2 & $70-79$ & Baik & 9 & $40,91 \%$ \\
\hline 3 & $60-69$ & Cukup & 3 & $13,64 \%$ \\
\hline 4 & $40-59$ & Kurang & 2 & $9,09 \%$ \\
\hline 5 & $0-39$ & Sangat Kurang & 0 & $0.00 \%$ \\
\hline
\end{tabular}

Jumlah

22

$100.00 \%$

Berdasarkan Tabel 4, hasil belajar siswa pada siklus II mengalami peningkatan. Kategori sangat baik yaitu sebesar $36,36 \%$ (8 siswa). Sebanyak 9 siswa $(40,91 \%)$ termasuk kategori baik, 3 siswa $(13,64 \%)$ termasuk kategori cukup, dan terdapat 2 siswa $(9,09 \%)$ yang hasil belajarnya termasuk dalam kategori kurang pada siklus II. Berdasarkan uraian tersebut diketahui bahwa hasil belajar siswa telah mengalami peningkatan dari hasil belajar siklus I dengan skor rata-rata hasil belajar secara klasikal sebesar 76,21 dengan kategori baik.

Analisis Peningkatan Hasil Belajar dari Prasiklus, Siklus I, dan Siklus II

Analisis Peningkatan Hasil Belajar dari Prasiklus, Siklus I, dan Siklus II dapat dilihat pada Tabel 5 berikut.

Tabel 5. Analisis Peningkatan Hasil Belajar dari Prasiklus, Siklus I, dan Siklus II

No. Kriteria Hasil Prasiklus Siklus I Siklus II Belajar

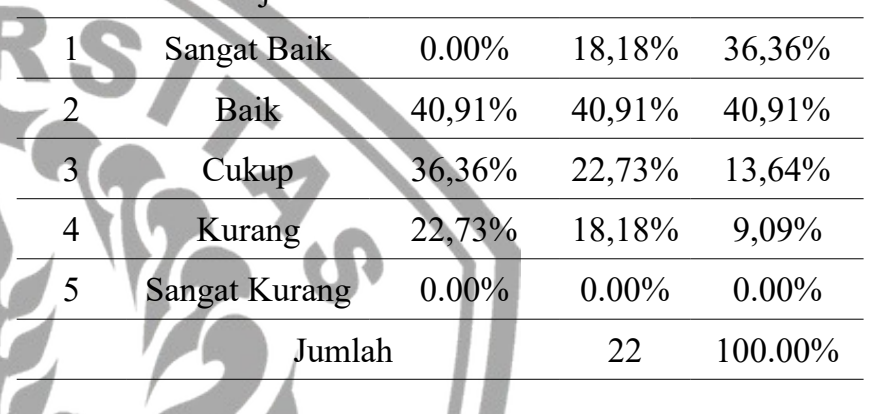

Peningkatan skor rata-rata hasil belajar siswa dari prasiklus, siklus I, dan siklus I dapat dilihat pada tabel 6 berikut.

Tabel 6. Peningkatan Skor Rata-rata Hasil Belajar

\begin{tabular}{|ccc}
\hline No. & Tahap & Skor Rata-rata \\
\hline 1 & Prasiklus & 64,81 \\
\hline 2 & Siklus I & 71,32 \\
\hline 3 & Siklus II & 76,21 \\
\hline
\end{tabular}

Berdasarkan Tabel 5 dan Tabel 6, hasil belajar siswa dari prasiklus, siklus I, dan selanjutnya siklus II mengalami peningkatan. Skor rata-rata hasil belajar siswa prasiklus secara klasikal sebesar 64,81 dengan kategori cukup. Setelah dilakukan siklus I terjadi peningkatan pada kategori sangat baik menjadi $18,18 \%$, kategori baik tidak mengalami perubahan yaitu tetap $40,91 \%$, kategori cukup mengalami penurunan menjadi $22,73 \%$, kategori kurang mengalami penurunan menjadi $18,18 \%$ dan tidak terdapat siswa yang termasuk dalam kategori sangat kurang. Skor rata-rata hasil belajar siswa secara klasikal pada siklus I sebesar 71,32 dengan kategori baik. Perolehan skor hasil belajar siswa pada siklus I masih perlu ditingkatkan lagi agar semua siswa mendapatkan hasil sesuai dengan yang diharapkan. Maka dari itu, dilakukan siklus II untuk memperbaiki kekurangan yang terjadi pada siklus I. Hasil belajar pada siklus II mengalami peningkatan pada kategori sangat baik menjadi $36,36 \%$, kategori baik tidak mengalami perubahan yaitu 
tetap $36.36 \%$, kategori cukup mengalami penurunan menjadi $13,64 \%$, kategori kurang mengalami penurunan menjadi $9,09 \%$, dan tidak terdapat siswa dalam kategori sangat kurang. Skor rata-rata hasil belajar siswa secara klasikal sebesar 76,21 dengan kategori baik.

Berdasarkan seluruh data analisis hasil belajar siswa menunjukkan adanya peningkatan dari prasiklus ke siklus I dan dilanjutkan ke siklus II. Skor rata-rata hasil belajar yang diperoleh siswa secara klasikal menunjukkan peningkatan yang lebih baik. Skor rata-rata hasil belajar siswa pada prasiklus 64,81 termasuk kategori cukup. Setelah dilakukan siklus I terjadi peningkatan skor rata-rata hasil belajar siswa secara klasikal sebesar 71,32 termasuk kategori baik. Skor hasil belajar siswa masih belum memuaskan, hal ini bisa dilihat dari masih terdapat 4 siswa dalam kategori kurang baik. Maka dari itu, dilakukan siklus II untuk memperbaiki kekurangan yang terjadi pada siklus I agar semua siswa mendapatkan hasil sesuai dengan yang diharapkan. Pada siklus II skor hasil belajar siswa secara klasikal meningkat menjadi 76,21 termasuk kategori baik.

Peningkatan hasil belajar siswa menunjukkan bahwa tingkat pemahaman siswa terhadap materi yang dipelajari semakin bagus. Hal ini dikarenakan pembelajaran dengan model pembelajaran kooperafif tipe Make $A$ Match melibatkan siswa secara aktif dalam pembelajaran dan mengajak siswa untuk lebih berkonsentrasi pada materi yang termuat dalam kartu soal dan kartu jawaban yang telah disesuaikan dengan tujuan pembelajaran.

\section{Kesimpulan dan Saran}

\section{Kesimpulan}

Berdasarkan hasil analisis dan pembahasan, maka dapat disimpulkan bahwa penerapan model pembelajaran kooperatif tipe Make A Match pada mata pelajaran IPS pokok bahasan perjuangan dalam mempersiapkan kemerdekaan Indonesia dapat meningkatkan hasil belajar siswa kelas VA di SDN Klatakan 01 Jember semester genap tahun pelajaran 2018/2019. Skor rata-rata hasil belajar siswa mengalami peningkatan dari prasiklus yaitu 64,81 (kategori cukup) pada siklus I menjadi 71,32 (kategori baik). Skor rata-rata hasil belajar siswa dari siklus I mengalami peningkatan yaitu dari 71,32 (kategori baik) pada siklus II menjadi 76,21 (kategori baik).

\section{Saran}

Berdasarkan kesimpulan di atas, maka penulis menyarankan (1) bagi guru, diharapkan model pembelajaran kooperatif tipe Make $A$ Match dapat dijadikan bahan pertimbangan variasi model pembelajaran untuk meningkatkan hasil belajar siswa, (2) bagi kepala sekolah, diharapkan dapat menjadi masukan untuk keefektifan dan pengelolaan dalam proses pembelajaran di SDN Klatakan 01 Jember, (3) bagi pengawas sekolah, diharapkan dapat menjadi masukan dalam upaya mengkoordinasi pelaksanaan inovasi pembelajaran di sekolah, dan (4) bagi peneliti lain, diharapkan hasil penelitian ini dapat dijadikan referensi untuk penelitian selanjutnya dalam menyusun penelitian yang sejenis dengan materi yang berbeda.

\section{Daftar Pustaka}

[1] Rusman. 2011. Model-model Pembelajaran Mengembangkan Profesionalisme Guru. Jakarta: Rajawali Pers.

[2] Huda, M. 2013. Model-model Pembelajaran dan Pengajaran. Yogyakarta: Pustaka Pelajar.

[3] Arikunto, S. 2012. Penelitian Tindakan Kelas. Jakarta: Bumi Aksara.

[4] Masyhud, M. S. 2016. Metode Penelitian Pendidikan. Jember: Lembaga Pengembangan Manajemen dan Profesi Kependidikan (LPMPK).

(1) 